\title{
Research-Based Teacher Education from Stake Holders Point: A Case Study
}

\author{
Lokanath Mishra ${ }^{1, *}$, Tushar Gupta ${ }^{2}$, Abha Shree $^{2}$ \\ ${ }^{1}$ Faculty Development Centre (FDC), Mizoram University, India \\ ${ }^{2}$ Department of Education, Mizoram University, India
}

Received May 7, 2020; Revised June 13, 2020; Accepted July 7, 2020

\section{Cite This Paper in the following Citation Styles}

(a): [1] Lokanath Mishra, Tushar Gupta, Abha Shree, "Research-Based Teacher Education from Stake Holders Point: A Case Study," Universal Journal of Educational Research, Vol. 8, No. 9, pp. 3895 - 3901, 2020. DOI: 10.13189/ujer.2020.080913.

(b): Lokanath Mishra, Tushar Gupta, Abha Shree (2020). Research-Based Teacher Education from Stake Holders Point: A Case Study. Universal Journal of Educational Research, 8(9), 3895 - 3901. DOI: 10.13189/ujer.2020.080913.

Copyright $\mathrm{C} 2020$ by authors, all rights reserved. Authors agree that this article remains permanently open access under the terms of the Creative Commons Attribution License 4.0 International License

\begin{abstract}
The postgraduate course of teacher education is based on research-based approach in teacher education in which all students will conduct a research and submit the dissertation as a part of their studies. Every teacher educators of this department are allotted one or two M.Ed. students to conduct research. The paper aims to study the teacher educators' and M.Ed. students' perceptions about research-based approach in teacher education and how theory and practice linked in teacher education. Both quantitative and qualitative methodologies are used for the study. Seventeen M.Ed. second semester students and 25 teacher educators were selected as the sample of the study. Data were collected through a questionnaire, interviews and Focus Group Discussion (FGD). The study indicates that teacher's educator appreciates the approach particularly based on research in the teacher's education. It is found that two-year M.Ed. programme was ideal for conducting research. The approach based on research in the teacher's education: students read educational research, learn research methods and research process, learn about research findings, and understand their relevance for practice.
\end{abstract}

Keywords Research, Teacher Education, Teacher Educators, Dissertations

\section{Introduction}

Teacher education is a part and parcel of the education system. It is closely related to society, and is influenced by a nation's ethos, history, and character. Constitutional priorities, state policy requirements, socio-economic concerns and awareness development, changing demands and changes in education, etc., call for a suitable response from a potential education system and provide the context from which teacher preparation systems need to be interpreted. Teacher educators are crucial players for maintaining and improving the high quality of the teaching workforce. They can have a significant impact on the quality of teaching and learning in our schools. Yet they are often neglected in policy-making, meaning that some Member States do not always benefit fully from the knowledge and experience of this key profession. It also means that the teacher educators do not always get the support and challenge they need, for example in terms of their education and professional development (European Commission 2013: 4). High quality teaching is now generally accepted as the most significant element at the school level impacting the achievement of the students. Furthermore, this has focused attention on the value of teacher training, from initial preparation and induction for new teachers to continue professional development to further improve the expertise of teachers, improve their knowledge and advance their skills as specialist practitioners (BERA-RSA,2014).The role of teacher training and professional development has been addressed by policy-makers around the world in different ways, reflecting their distinctive values, attitudes and expectations about the essence of specialized competence 
and how and where such erudition takes place. A UK teacher education study (BERA-RSA, 2014) described four different ways work that can subsidize teacher training: (1) the content of the teacher education curriculum is focused on evidence-based knowledge; (2) evidence guides the design and implementation of teacher education programmes; (3) teachers and teacher educators are prepared to participate in the study as well as consumers; and (4) teachers and teacher educators perform research into their own practice. The study suggests that both schools and colleges should become research-rich environments, encouraging teachers and researchers to collaborate instead of doing their work as entirely separate organisations. Teacher training is an education involving multidisciplinary standpoints and experience, plans and principles that are created, and practised and learned under the best teacher educators. Teachers must be grounded in Indian values, tradition, expertise, and traditions while also being well versed in recent developments in education and pedagogy. Teacher training requires adequate time and space to develop instructional experiences, and understanding of subject matter and pedagogy, as well as developing an identity as a teacher-theory must be translated into continuous graded practice for this. It is predominantly achieved in an atmosphere of genuine multidisciplinary expertise. There is an age-old debate regarding 'theoretical' and 'practical' understanding in teacher education. In the USA and the UK, teacher professionalism is restricted. (Menter 2015). In the USA, a new way of teaching is emerging in teacher education which is practically based (Zeichner 2014). In the UK, except for Scotland, teacher education programme is school-based teacher training which is the outcome of research-based teaching (Gilroy 2014). Findings of the research say that preservice teacher faced difficulties while applying the theoretical knowledge in the classroom situation, therefore, our preservice teachers' compositions included in the teacher education agenda do not concoct them to face the real situation of classroom (Klette, et.al 2006). To bridge the difference between theoretical and realistic teacher training, emphasis should be laid on teacher education - not only lesson scheduling and teaching preparation, microteaching of existing teaching methods, but also cooperation with colleagues, tutoring students with exceptional needs and issues, and managing classrooms (Westbury, Hansén, Kansanen, and Björkvist, 2005). Research-based teacher education will increase interest among teacher educators (Kansanen et al., 2000; Jakku-Sihvonen.et.al.2006). Research-based teacher education has two aspects. One aspect of the 'research-based' is 'evidence-based' which can be used as a guideline for further development of the teacher's education. The form of teacher education focused on research is teacher pedagogical theory and research-based instruction, which is the key theme for coordinating teacher education programs. Out of many approaches to teacher education research-based approach is the appropriate one (Kansanen, 2006). Research- thought is about translating the theoretical aspects into practice. Pedagogical material is the most critical skill for a student teacher, like awareness and asking pedagogically relevant questions in it. Zeichner identified four main determinants in teacher education which are totally based on research. First, the teacher's education curriculum is designed systemically, secondly, all teaching is focused on learning, thirdly, lessons are well coordinated, and fourthly, students develop various research skills during their Master's degree (Kansanen, Tirri, Meri, Krokfors, Husu, \& Jyrhämä, 2000; Kansanen, 2004; Jakku-Sihvonen, 2006; Krokfors, 2007). A model of the core theoretical elements of research-based teacher education is given below (Toom, et.al, 2008).

Table 1. The two-fold practice on the basic and general level of research-based teacher education

\begin{tabular}{|c|c|c|}
\hline \multicolumn{3}{|c|}{ RESEARCH-BASED TEACHER EDUCATION } \\
\hline & TEACHING & RESEARCH \\
\hline GENERAL & $\begin{array}{ll}- & \text { Metacognition } \\
\text { - } & \text { Reflection } \\
\text { - } & \text { Pedagogical } \\
& \text { thinking } \\
\end{array}$ & $\begin{array}{ll}\text { - } & \text { Producing } \\
\text { - } & \text { Expertise }\end{array}$ \\
\hline \multirow[t]{2}{*}{ SPECIFIC } & $\begin{array}{ll}- & \text { Everyday } \\
\text { thinking } \\
\text { - } & \text { Skills-based } \\
& \text { teaching } \\
\text { - } & \text { Teaching recipes, } \\
& \text { routines, tips }\end{array}$ & $\begin{array}{ll}- & \text { Adaptation } \\
- & \text { Consuming } \\
- & \text { Knowledge-based }\end{array}$ \\
\hline & $\begin{array}{c}\text { Making pedagogical } \\
\text { decisions }\end{array}$ & $\begin{array}{l}\text { Inquiring one's own } \\
\text { work }\end{array}$ \\
\hline
\end{tabular}

Source-file://C:/Users/HP/Downloads/Exploring_the_essential_charact eristics_of_researc.pdf

\section{Two Levels of Teacher Education}

The core teacher's education level is the first aspect of the teacher education programs centred on research. This degree focuses on fundamental knowledge, practical skills maturity and awareness of the pedagogical material courses. (Gage, 1978; Kansanen, and others, 2000). This kind of thought partially explains why there is still a misconception that teachers are born-but not prepared. The development of these skills is consistently and continuously assisted in teacher education. Wilson, Floden and Ferrini-Mundy (2001) propounded that the student's achievement was substantially enhanced by the pedagogical material awareness courses based on simple subject matters. Beyond this fundamental level of an approach based on research, there is a need for a more general level of teacher's education aimed at the continuous growth in the teacher's work. When related to the basic level, the general level is different from the realistic every day's work of the instructor. It applies to the activities related to thinking, feeling, debate and other research. A general degree mainly means a sort of 
metacognition of one's own job and decisions which are to be taken in pedagogy. Identifying pedagogical elements and asking pedagogically meaningful questions in educational situations are among the most important skills for a future teacher needs. In line with Zeichner's definition, we have outlined four key determinants in our research-based teacher education. Firstly, the study programme is structured according to the systemic educational structure, secondly all teaching is based on research, and thirdly, activities are organized so as to give students the opportunity to practice argumentation, decision making and justification when inquiring and solving pedagogical problems. Fourthly, students learn different research skills during their studies when they proceed to the Master Thesis level (Kansanen, Tirri, Meri, Krokfors, Husu, and Jyrhämä, 2000; Kansanen, 2004; Jakku-Sihvonen and Niemi, 2006; Krokfors, 2007.). Therefore, teacher education focused on research may be perceived as a field from the main to the general level. Currently there are also efforts to engage student teachers in research (Smith and Sela, 2005; Ulvik, 2014).

India's teacher education has to be tailored to the tasks teachers undertake when they enter the profession. The teacher education must also be closely associated with the school curriculum. But the teacher educators themselves have no school teaching experience at all. We teach pupil teachers mostly the theoretical courses and seldom seek to equip the required teachers with skills that are necessary for coping with real school teaching issues such as techniques for managing large classes, coping with multi-grade and multi-level teaching, etc. Therefore, the National Council for Teacher Education (NCTE) has recommended the correct $\mathrm{M}$.Ed. The courses are structured to prepare teacher-specific stages (Maheshwari, A.N., 1998). Research-based teacher education has lately received increasing interest both among re-searchers of teacher education (e.g. Kansanen et al., 2000; Jakku-Sihvonen and Niemi, 2006, 2007) and in public discussion. India's proposed National Education Policy 2019 outlines teacher preparedness based on the study. It states that:

"Departments of Education of universities will support vibrant research groups that will conduct many field experiments, and all faculty members will be encouraged to engage in research. The last thirty years have seen significant developments in educational research and understanding of how students learn, on teacher preparation, and on how schools can function to achieve quality in learning. These developments have been possible through research internationally, and several innovative field experiments that are uniquely Indian. The discipline of education and the practice of teacher education must draw on the best of these to provide student-teachers with rich understanding and practices that draw from Indian efforts and innovations, and from the contextualized global best. It will be ideal to have teacher preparation take place in centres of research and field action which offer a vibrant ambience of research and innovation in which knowledge and practice can be formed. Research-based teaching and specialization will ensure that knowledge and practices are contemporary and up-to-date, and relevant to the current contexts of schools and higher education."

One out of seven sisters of north-eastern India is Mizoram, which is bordered by Myanmar (formerly known as Burma) to the east and south, Bangladesh to the west, and the northern states of Assam, Manipur and Tripura. Mizoram means 'Land of the Highlanders' and their local language is Mizo. The Mizo Hills that govern the topography of the state rise to more than $2000 \mathrm{~m}$ $(6560 \mathrm{ft})$ near the border with Myanmar. Aizawal, the capital of the state, stands at $1220 \mathrm{~m}(4000 \mathrm{ft})$ above the sea level. The state occupies an area of total 8,139.4 sq. mi or roughly $21,087 \mathrm{sq}$. $\mathrm{km}$. According to the 2011 census, the State's population is 1,091,014. Mizoram has 8 districts with 22 towns and 817 villages namely Lawngtlai, Lunglei, Aizawl, Kolasib, Serchhip, Mamit, Saiha, and Champhai. Mizoram consists of a comprehensive education system ranging from elementary education to university education, training to professional training. The State had the third highest literacy rate in the country by the 2011 census, i.e. 92 percent. There are about 4,393 schools, 2,93,170 enrolled students, 23,665 teachers and the Pupil Teacher Ratio (PTR) is 1:12. There are four institutions offering B.Ed. programme and two institutions offering M.Ed. programmes under Mizoram University. The research was mainly conducted in the education department, University of Mizoram. The M.Ed. course was designed which is a research-based approach in teacher education. In the two-year M.Ed. programme, all students will conduct a research and submit the dissertation as a part of their studies. All teacher educators of this department are allotted one or two M.Ed. students to conduct research. In order to know the perceptions of teacher educators which are based on research-based teacher education the study was conducted with the following objectives.

\section{Objectives}

1) To study the teacher educators' perceptions of the research-based approach in teacher education

2) To study the perceptions of M.Ed. students of the research-based approach in teacher education

3) To research the view of teacher educators in teacher education on the relationship between theory and practice. 


\section{Methodology}

The researcher used both quantitative and qualitative methodologies to study the observations of stakeholders based on the research approach in teacher education. All 17 M.Ed. second semester students of Mizoram University and 25 teacher educators (Five professors, one associate professor, and nineteen assistant professors) of the education department, Mizoram University were selected as the sample of the study. A questionnaire was developed in a workshop and this was used to gather the data from the students, and teacher educators. An interview was scheduled to gather data from teacher educators 'opinions regarding teacher education based on research. A Focus Group Discussion (FGD) for M.Ed. students was organised All the teacher educators and students extended their full cooperation with their opinions and valuable suggestions. Out of the interpretation and presentation of the study's results a thematic approach was taken. Data obtained from the various sources were triangulated and analyzed by using the frequency distributions and percentages. Due to a small number of respondents, we used just concise statistics on looking at data. With these findings response was made to the foremost research issue. The data were analyzed using qualitative content analysis.

\section{Findings}

A research-based teacher education is merely the use of another's work for others in the processes of teaching and learning; there are also expectations that teacher educators and students should become large producers. All teacher educators shared optimistic opinions on teacher education based on research. Teacher education in India is under the higher education system. All such teacher educators are supposed to read research in the acquisition of necessary information as well as undertake research skills to become teacher educators. All Teacher educators expressed that publishing of research papers for their career advancement or promotion is required. So, research at M.Ed. level is useful and informative in creating one's own perception and awareness. Most of the teacher educators said that research in teacher education should be practice oriented research for teacher preparation. Dissertation plays an important role in bridging the gap between theory and reality. Action oriented research must be undertaken by the department of education was the perception of teacher educators regarding research-based teacher education. Teacher educators accepted that the courses correlated to the domain of research methodology to be included from the beginning of the M.Ed. course. All teacher educators perceived that research at M.Ed. level is the stepping stone for perusing Ph.D. degree in teacher education. The respondents said that the approach purely based on research is better understood if the students participate in the research work of their own. Most of the teacher educators (22) perceived that research on pedagogical content knowledge should be taken at M.Ed. level. All teacher educators thought the approach which is solely based on research; to be included in their own school subject matter was significant. Most of the teacher educators (17) perceived that the dissertation at the master level being conducted in two years is good, but students are taking it easy in the beginning and finishing it hurriedly at the end of the fourth semester. Some teacher educator (5) believed that students may come across the theoretical knowledge of the construction of tools, the procedure of data collection and analysis procedures before writing the master dissertation, so as to integrate their theoretical knowledge to practical knowledge. All professors viewed that over the course of time, teacher educators' and would be teacher educators work has been supervised by senior professors as well as by teachers themselves. Regarding the choice of the topic for dissertation, students usually come to their supervisor with an understanding that whatever topic the supervisor will assign, they will continue with that topic. Teacher educators considered that teaching is 'research-based' in universities or higher education institutions, like teacher education. In other words, teacher education focused on research often applies to the instruction delivered by the teacher educators. All Professors, Associate Professors and Assistant Professors agreed that they follow the latest research in their field and apply it for dissertation writing of M.Ed. students.

During the interview, one teacher educator said that "I personally feel that M.Ed. level dissertation is an opportunity for testing their research skills by the novice supervising academician who wishes to polish their research and research methodology skills of both qualitative and quantitative researches. In research-based teacher education many new ideas come to the surface, many old doubts are clarified, new permutations and combinations are formed and non-working ideas are dropped. Many students can be asked to study the same problem using different research techniques in collaborative projects and later the data can be compiled and subjected to the triangulation of data for its validity. Training into a data analysis software packages such as Advance Microsoft Excel, SPSS, $R$ software, etc. can also be tried. In total the scholar must have a return value of the knowledge gained during his/ her experience and vice versa contribute fruitfully to the academia through her/his thesis."

Now it has become a difficult task to write a paper in journals and periodicals for M.Ed. students and it has become a prerequisite nowadays to get a job at university or as college teachers. So, research must be a part of M.Ed. programme. One Associate professor expressed that "having research articles in journals used to be a matter of pride nowadays. Today, it is not just a matter of pride but a necessity now that employment in colleges and universities now considers at least three research articles as a qualification for entry. Doing a minor research work will 
enable the student to gather a number of reliable data, analyze them, and publish the findings in educational journals. This will not only give them more confidence but enrich their body of work when they go in search of jobs. Writing a dissertation is useful because, being practical in nature; the students have a chance to get a first-hand experience of certain subject matters which will give them a much deeper understanding than mere theoretical study. Having a specialization subject is important from a professional point of view. The student will certainly have some specialization in his dissertation area when compared with others who have not written in the subject. This will give him an edge over others at the time of job hunting again. Therefore, it is fortunate that dissertation writing is a part of the course in M.Ed. at Mizoram University".

Almost all the teacher educators reported that integration of research and practice is required in students' pedagogy whereas on reflection, practice was emphasised, experimenting and modelling practice of teaching was less utilised. Practice and theory are bounded institutionally. The teacher educators of Mizoram University said that the research which is based on the teacher's education "requires a more integrated relationship between theory and practice, between the academic and the practitioner, the department of teacher education and the school." In FGD one teacher educator said that "we are teaching about lesson plans in teacher training institutions, but when the teacher enters in the profession he is not using this lesson plans to transact the lesson, so research must be done on how to link with theory and practice in teacher education system of India". One suggests that the syllabus of research methodology needs to be revised and more emphasis must be given to practical work rather than theoretical work. However, the research paper at M.Ed. level of Mizoram University is $50 \%$ theory and $50 \%$ dissertation writing".

Most of the students (15) appreciate that the research totally based on the teacher's education is most appropriate in India nowadays. They viewed that the research which is based on teacher's education is beneficial to the teachers, the colleagues, the pupils, their families, and wider society. In a major portion of the M.Ed through the teacher's education, students had a positive attitude towards inquiry and reflection, and regarded teacher study as a way to improve their professional growth. The M.Ed students acknowledged that writing the methodology part is challenging and difficult at the postgraduate level of teacher education. They understood the objectives and meaning of the dissertation at M.Ed. level and were not at all clear on its relationship to the teaching profession. The majority of M.Ed. Students had a positive view that writing a dissertation equipped them with deep knowledge of a subject, well-tuned professional language, and the ability to continue with practically oriented research. Most of the students said that although in National Eligibility Test
(NET) for teacher educators or Asst. Professors and Junior Research Fellow (JRF) more questions were asked from research methodology, but it is important to study research methodology and writing a dissertation at M.Ed. level. Educational science is the main subject of the teacher's education. Many students viewed that the research purely based on teacher's education is related to research-related courses, content, and literature, methodology, and statistics. All students agreed that during a specific paper on research methodology, they gained insights on scientific theories, quantitative and qualitative methods, and the rules of academic writing. With regards to the status, quality, standard, and development of research-based teacher education M.Ed. students appreciated it. During FGD one student expressed that "research-based teacher education assures well-educated and technically knowledgeable teachers. The fact is that research-based education gives more knowledge and is the actual requirement of the society". During M.Ed. courses students agreed that they learnt research methodology and its use in their own research projects. One student expressed that "as it was my first-time performing research in education, for selecting the topic of my research required lots of time to finalize the topic. Though we enter the research gate, I could not get many benefits from the research subject that we've been tough inside the classroom because it was difficult for the beginner to clearly understand the concept of different topics of the research paper. Especially the statistic paper of research teaching was not satisfactory for me to finish up my entire dissertation in entering my data collection and analyses it. I think for more convenience for the junior of M.Ed. students, more priority should be given to terms of studying statistics including all research paper so that it could also be helpful for passing out of the UGC NET exam for the student".

The M.Ed. programme of Mizoram University is designed in such a way (M.Ed. Secondary and M.Ed. elementary) that students develop their critical thinking skills. Within research-based teacher education, students learn to think, reflect, and examine information in a critical way. M.Ed. students agreed that with an international perspective, research-based teacher education of Mizoram University is not common. It has its importance for the prospect of the teaching profession. In FGD "The 4th semester is the time for finalizing the dissertation, I think we could be given more time in terms of analyzing our research. If the other paper activities can be reduced in terms of submitting our dissertation paper, it could be more privileged for the students, and reduced the stress of attaining a few number of activities." A research-based approach further enhances the ability to search for reliable information and develop critical thinking as expressed by the M.Ed. students.

One teacher educator expresses that "If research is a required component of teacher educators' work, then research must also be addressed in terms of research 
facilities, and, in addition to building communities of research in the department/faculty, time and resources are fundamental conditions for conducting research. As long as researching teacher educators are expected to engage in research on top of full-time teaching requirements, it will be difficult to create a research-based teacher education. Conducting research is time-consuming, and the demand for research has to be highly correlated with the time and resources allotted to it, especially for new researchers who are also going through a process of learning the skill". This is very similar to the study conducted by Kari Smith, (2015)

\section{Conclusions}

Drawing on the outcomes from this study, it indicates that teacher's education appreciates the approach based on research in the teacher's education. Many of the respondents considered a two-year M.Ed. System was ideal for conducting research. This approach based on research in the teacher's education: students read educational research, learn research methods and research process, learn about research findings, and understand their relevance for practice which is very similar to the findings of other researches (Healey, 2005; Kansanen, 2006; Toom et al., 2010; Jenset, Klette and Hammerness, 2017) who conducted educational research at M.Ed. level and built connections between research and practice of teaching during teacher education. You will incorporate both qualitative and quantitative analysis work at M.Ed. Dissertation or thesis writing redefines the students' capabilities and potentialities in the subject of their different interest areas. Fundamental research is consequential for an academic career as it generates a stock of knowledge and facilitates new learning. Research also facilitates a better understanding of various issues in the teacher education. Research in the teachers' education will enhance the teacher's capability, research capability of students, institutional capacity and national research strategy and its infrastructure. The findings of this study indicate that a research base for teacher education is highly relevant, and a research approach can be an indicator of achieving quality and further promoting teachers' professional competence. The findings of this study specify that students are able to write texts with scientific content and formulation, and they learn to perform their own research at M.Ed. level. Writing a dissertation at M.Ed. level equipped the students with deep knowledge of a subject, well-tuned professional language, and the ability to continue with practically oriented research. Students also learn how to use various methods and carry out their own research projects. Teacher educators also learn to see relationships between different methods and learning results, and they can use the knowledge they find to improve their own teaching. The findings of the study reveal that research-based approach enhances the ability to explore the reality and develop critical thinking of the students. All research is useful for academic education; however, practice-oriented research, which is useful to the practice field and can lead to changes in schools and teacher education, is of great relevance to the teacher education community, school teachers and leaders, and policy-makers. Becoming a researcher is a hands-on learning process, and there ought to be opportunities for all teacher educators to engage in supported development processes as researchers.

A research-based education represents a high-level of competence; expert knowledge, status, and good job opportunities would be teacher educators. Research in educator edification concerns all those involved: student teachers and teacher instructors as well as teacher edification institutions and field schools through curriculum, pedagogy and research. Educational research and practice are intrinsically connected and this is a strong basis for integration and Research capacity building needs to encompass all stakeholders and levels of intervention (individual, organisational, systemic)

\section{REFERENCES}

[1] BERA-RSA. (2014). Research and the teaching profession: Building the capacity for a self-improving system. Final report of the BERA-RSA inquiry into the role of research in teacher education. https://www.thersa.org/globalassets/pdfs /bera-rsa-research-teaching-profession-full-report-for-web2.pdf downloaded on 21/02/2020

[2] BERA-RSA, (2014). the role of research in teacher education: reviewing the evidence, https:/www.thersa.org/ discover/publications-and-articles/reports/the-role-of-resear ch-in-teacher-education-reviewing-the-evidence?gclid=Cjw KCAjw3-bzBRBhEiwAgnnLCoPjogZDATd6X2MaPrn9H EKQ1n9IJO6qucJbLoCn-opSXgZ-WkZKixoC7hEQAvD_ BwE, downloaded 23/03/2020

[3] European Commission (2013). Supporting teacher educators for better learning outcomes. Brussels: European Commission.

[4] Gage, N. (1978). The scientific basis of the art of teaching. New York: John Willey.

[5] Gilroy, P. (2014). Policy interventions in teacher education: sharing the English experience. Journal of Education for Teaching 40 (5), pp.622-632.

[6] Healey (2005) Linking Research and Teaching to Benefit Student Learning, Journal of Geography in Higher Education Volume 9(2) https://www.tandfonline.com/doi/a bs/10.1080/03098260500130387 downloaded 7/11/2019

[7] Jakku-Sihvonen, R. and Hannele N. (Eds.). (2006). Research-based teacher education in Finland - Reflections by Finnish teacher educators. Research in Educational Studies 25 .

[8] Jenset, Klette and Hammerness (2017) Grounding Teacher Education in Practice Around the World: An Examination of 
Teacher Education Coursework in Teacher Education Programs in Finland, Norway, and the United States, https://journals.sagepub.com/doi/full/10.1177/00224871177 28248 downloaded on $12 / 02 / 2020$

[9] Kari Smith, NTNU and University of Bergen (2015) The role of research in teacher education, https://pdfs.semantics cholar.org/9131/f830b71ce291ebf9c81515b6c33311a63613 .pdf

[10] Kansanen, P. (2006). Constructing a research-based program in teacher education. In F.K. Oser, F. Achtenhagen, \& U. Renold (Eds.), Competence oriented teacher training. Old research demands and new pathways (pp. 11-22). Rotterdam $\&$ Taipei: Sense Publishers.

[11] Kansanen, P. et.al (2000). Teachers' pedagogical thinking. Theoretical landscapes, practical challenges. New York, Peter

Lang.https://www.ltu.se/cms_fs/1.4762!/kansanenspeech.pd f downloaded on $25 / 02 / 2020$

[12] Kansanen, P., Tirri, K., Meri, M., Krokfors, L., Husu, J., and Jyrhämä, R. (2000). Teachers' pedagogical thinking. Theoretical landscapes, practical challenges. New York, Peter Lang.

[13] Klette, K. et.al (2006). Changes in Nordic Teaching Practices: From individualised teaching to the teaching of individuals, Scandinavian Journal of Educational Research Vol. 50(3) pp. 301-326 https://www.mv.helsinki.fi/home/hs imola/Changes\%20in\%20Nordic\%20Teaching\%2006.pdfd ownloaded 13/01/2020

[14] Krokfors, L. (2007). Two-fold role of pedagogical practice in research-based teacher education. In R. Jakku-Sihvonen, and H. Niemi. (Eds.), Education as a societal contributor. Reflections by Finnish educationalists. Frankfurt am Main: Peter Lang.

[15] Maheshwari, A.N. (1998) Curriculum Framework for Quality Teacher Education. http://anmaheshwari.net/ncte.ht $\mathrm{m}$ downloaded on 5/12/2019
[16] Menter, I. (2015). Teacher Education. International Encyclopaedia of the Social and Behavioural Sciences (2nd ed.), 24, pp.51-55.

[17] MHRD (2019) Draft National educationalPolicy,2019, https://mhrd.gov.in/sites/upload_files/mhrd/files/Draft_NE P_2019_EN_Revised.pdf downloaded on 11/11/2019

[18] Smith, K. (2011). 'The multi-faceted teacher educator - a Norwegian perspective'. Journal of Education for Teaching, 37(3), pp.337-49.

[19] Smith, K. and Sela, O. (2005). 'Action Research as a bridge between pre-service teacher education and in-service professional development'. The European Journal of Teacher Education, 28(3), 293-311.

[20] Toom, A., et.al (2010). Experiences of a research-based approach to teacher education: Suggestions for future policies. European Journal of Education, 45, pp.331-344.

[21] Ulvik, M. (2014). 'Student-teachers doing action research in their practicum: why and how?' Educational Action Research, 22(4), pp.518-33. (doi: 10.1080/09650792.2014. 918901)

[22] Westbury, I., Hansén, S. E., Kansanen, P., and Björkvist, O. (2005). Teacher education for research-based practice in expanded roles: Finland's experience. Scandinavian Journal of Educational Research,49, pp.475-485. https://www.tandfonline.com/doi/abs/10.1080/0031383050 0267937? scroll $=$ top $\&$ needAccess $=$ true $\&$ journalCode $=$ csje 2 0downloaded on 14/12/2019

[23] Wilson, S., Floden, R. and Ferrini-Mundy, J. (2001). Teacher preparation research: Current knowledge, gaps, and recommendations. Washington, D.C.: Center for the Study of Teaching and Policy. University of Washington.

[24] Zeichner, K. (2014). The struggle for the soul of teaching and teacher education in the USA. Journal of Education for Teaching 40(5), pp.551-568. 